\title{
Effects of changes in moisture source and the upstream rainout on stable isotopes in precipitation - a case study in Nanjing, eastern China
}

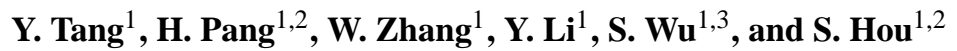 \\ ${ }^{1}$ Key Laboratory of Coast and Island development of Ministry of Education, School of Geographic and Oceanographic \\ Sciences, Nanjing University, Nanjing 210023, China \\ ${ }^{2}$ Collaborative Innovation Center of Climate Change, Jiangsu Province, China \\ ${ }^{3}$ Geology Department, University of Dayton, Ohio 45469-2364, USA
}

Correspondence to: H. Pang (hxpang @nju.edu.cn) and S. Hou (shugui@ nju.edu.cn)

Received: 22 February 2015 - Published in Hydrol. Earth Syst. Sci. Discuss.: 15 April 2015

Revised: 8 October 2015 - Accepted: 13 October 2015 - Published: 22 October 2015

\begin{abstract}
In the Asian monsoon region, variations in the stable isotopic composition of speleothems have often been attributed to the "amount effect". However, an increasing number of studies suggest that the "amount effect" in local precipitation is insignificant or even non-existent. To explore this issue further, we examined the variability of daily stable isotopic composition $\left(\delta^{18} \mathrm{O}\right)$ in precipitation from September 2011 to November 2014 in Nanjing, eastern China. We found that intra-seasonal variations of $\delta^{18} \mathrm{O}$ during summer were not significantly correlated with local rainfall amount but could be linked to changes in the moisture source location and rainout processes in the source regions. Our findings suggest that the stable isotopes in summer precipitation could signal the location shift of precipitation source regions in the inter-tropical convergence zone (ITCZ) over the course of the monsoon season. As a result, changes in moisture source location and upstream rainout effect should be taken into account when interpreting the stable isotopic composition of speleothems in the Asian monsoon region. In addition, the temperature effect on isotopic variations in non-monsoonal precipitation should also be considered because precipitation in the non-monsoon season accounts for about half of its annual precipitation.
\end{abstract}

\section{Introduction}

The "amount effect" refers to the observed negative correlation between the isotopic composition in precipitation and rainfall amount. It was first proposed by Dansgaard (1964), and is generally observed in low-latitude regions (AraguásAraguás et al., 1998). Based on this relationship, stable isotopic records obtained from low-latitude regions are often used for paleohydroclimate reconstructions (Cruz et al., 2005, 2009; Partin et al., 2007; Tierney et al., 2008; Sano et al., 2012). However, some recent studies suggest that the "amount effect" is insignificant or even non-existent in lowlatitude monsoon areas. For example, Conroy et al. (2013) found spatial and temporal examples of precipitation-isotope mismatches across the tropical Pacific, indicating that factors beyond the "amount effect" influenced precipitation isotope variability. They compared 12 isotope-equipped global climate models to assess the distribution of simulated stable isotopic variability. Model simulations support observations in the western tropical Pacific, showing that monthly $\delta^{18} \mathrm{O}$ are correlated with large-scale, not local, precipitation (Conroy et al., 2013). Peng et al. (2010) also found no significant correlation between precipitation amount and $\delta^{18} \mathrm{O}$ values in the western Pacific monsoon region near Taiwan. They suggest that moisture sources of diverse air masses with different isotopic signals are the main factor controlling the precipitation isotopic characteristics. Breitenbach et al. (2010) observed no empirical amount effect at their study site in the monsoonal northeastern India. They identified a strong 

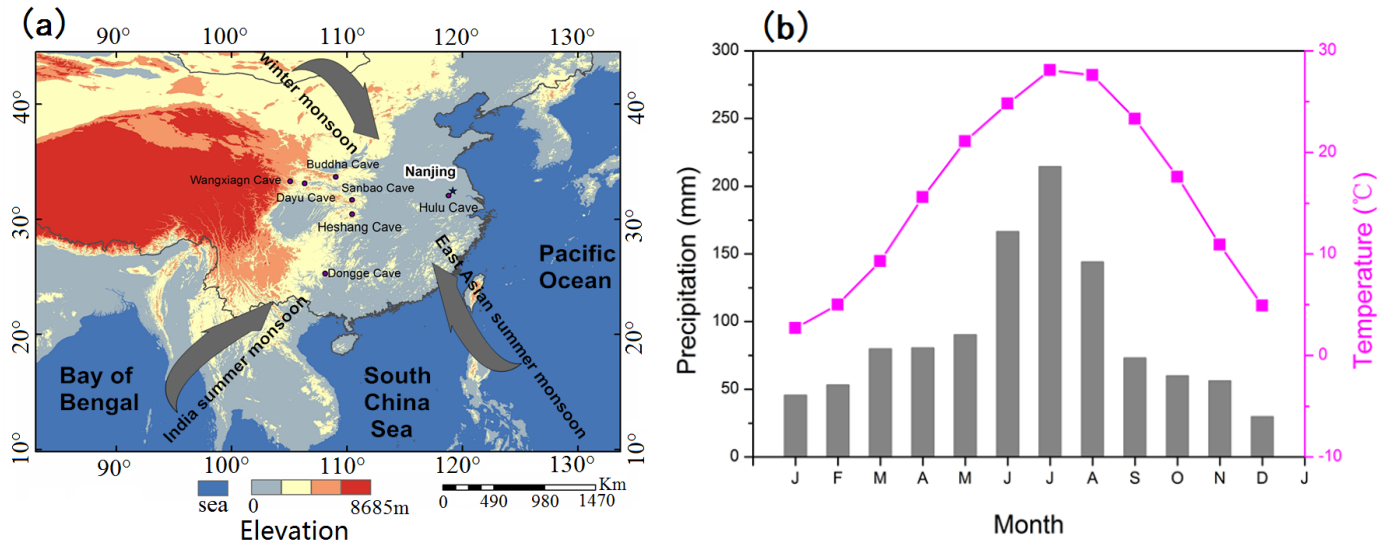

Figure 1. (a) Elevation map of China; the study site Nanjing is marked by a black star. Black dots indicate the cave locations mentioned in this study: Hulu, Dongge, Heshang, Sanbao, Wanxiang, Buddha, and Dayu. Grey arrows indicate the dominant circulation patterns over the region in summer and winter. (b) Monthly average temperature and precipitation from 1981 to 2010 at Nanjing (data from the China Meteorological Data Sharing Service System).

trend towards lighter isotope values over the course of the summer monsoon, with lower $\delta^{18} \mathrm{O}$ and $\delta \mathrm{D}$ values late in the monsoon season and a temporal offset between the highest rainfall and the most negative $\delta^{18} \mathrm{O}$. Other observations (Lawrence et al., 2004; Kurita et al., 2009) show that, at marine island stations, even short-term (daily or event-based) isotopic variations are independent of local precipitation intensity but are instead linked to rainout processes in the surrounding regions. Some ice core studies also suggest that records of precipitation $\delta^{18} \mathrm{O}$ in ice cores of the Indian monsoon region do not match the local precipitation amount. For example, Pang et al. (2014) found a significant correlation between $\delta^{18} \mathrm{O}$ records from the East Rongbuk ice cores and summer monsoon rainfall along the southern slope of the Himalayas, whereas no significant correlation was found between the $\delta^{18} \mathrm{O}$ records and accumulation rates (an indicator of local precipitation). This suggests that summer monsoon precipitation $\delta^{18} \mathrm{O}$ over the high Himalayas are controlled by the upstream rainout over the entire southern slope of the Himalayas rather than local precipitation processes.

Stable oxygen isotopes in speleothems are widely used for paleoclimate reconstructions. Recently, stable oxygen isotopes measured in cave speleothems from China have received much attention, e.g., from the Hulu Cave (Wang et al., 2001), Dongge Cave (Yuan et al., 2004; Dykoski et al., 2005; Kelly et al., 2006), Sanbao Cave (Wang et al., 2008; Cheng et al., 2009), Heshang Cave (Hu et al., 2008), Wanxiang Cave (Zhang et al., 2008), Buddha Cave (Paulsen et al., 2003), and Dayu Cave (Tan et al., 2009) (Fig. 1a). However, the interpretation of these stable isotope records in speleothems remains controversial. Some researchers used the stable isotope records from stalagmites in monsoonal eastern China as proxies for precipitation amount (Hu et al., 2008; Tan et al., 2009; Cai et al., 2010). Paulsen et al. (2003) showed that short-term $\left(<10\right.$ years) variations in $\delta^{18} \mathrm{O}$ in stalagmites from the Buddha Cave reflect changes in precipitation amounts, but longer-term (>50 years) $\delta^{18} \mathrm{O}$ variations are related to changes in air temperature. Other studies suggest that $\delta^{18} \mathrm{O}$ indicate changes in the ratio of summer/winter precipitation, which they refer to as "monsoon intensity" (Wang et al., 2001; Yuan et al., 2004; Dykoski et al., 2005; Kelly et al., 2006; Wang et al., 2008; Zhang et al., 2008; Cheng et al., 2009). Dayem et al. (2010) reported that annual and rainy season precipitation totals in central China, southern China, and eastern India have correlation length scales of $\sim 500 \mathrm{~km}$, shorter than the distance between many speleothem records that share similar long-term time variations in $\delta^{18} \mathrm{O}$ values. Thus, the short correlation distances do not support the idea that apparently synchronous variations in $\delta^{18} \mathrm{O}$ values at widely spaced $(>500 \mathrm{~km})$ caves in China are due to variations in annual precipitation amounts. Most of the abovementioned studies indicate that the variations of $\delta^{18} \mathrm{O}$ in speleothems from the Asian summer monsoon region are not controlled by the local precipitation amount.

Recent studies have revealed the importance of variability in moisture sources (Peng et al., 2010; Xie et al., 2011) and large-scale convective activities (Vimeux et al., 2011; Tremoy et al., 2012; Kurita, 2013; Moerman et al., 2013; Lekshmy et al., 2014; He et al., 2015) in controlling precipitation $\delta^{18} \mathrm{O}$ in monsoon regions. Strong convection at source regions tends to produce more precipitation, causing heavy isotopes to preferentially condense from vapor, leading to lower values of downstream precipitation $\delta^{18} \mathrm{O}$. In addition, the location of moisture source determines the distance that water vapor has to travel, hence affecting the precipitation $\delta^{18} \mathrm{O}$. Soderberg et al. (2013) found that the variability of the isotopic composition of individual rain events in central Kenya could be partly explained by the distance traveled by an air mass over land. Therefore, the rainout effect at the water vapor source areas and upstream regions should have 
a significant influence on stable isotopes in precipitation in downstream regions (Vuille et al., 2005).

In the Asian monsoon regions, moisture sources for summer precipitation often lie in the strong convection areas within the inter-tropical convergence zone (ITCZ). The variability of the ITCZ position and intensity could therefore affect precipitation $\delta^{18} \mathrm{O}$ in these regions. Using the outgoing longwave radiation (OLR) as a tracer for deep tropical convection (Wang et al., 1997), the ITCZ position and strength can be identified (Gu and Zhang, 2002). In the East Asia-western Pacific region, the onset of the Asian summer monsoon corresponds to the northward movement of the ITCZ to an area $5-25^{\circ} \mathrm{N}$ (Ding, 2007) and brings with it large amounts of convective precipitation (Ananthakrishnan et al., 1981). In this study, we focused on a detailed examination of how summer precipitation $\delta^{18} \mathrm{O}$ related to changes in the position and intensity of moisture sources within ITCZ, using the daily $\delta^{18} \mathrm{O}$ data at Nanjing in summer (June-September) during 2012-2014, the daily OLR data, and relevant meteorological data. However, according to long-term monthly means of Nanjing precipitation for the years 1981-2010 from the China Meteorological Data Sharing Service System (http://cdc.nmic.cn/home.do), summer precipitation (June-September) accounts for $54.8 \%$ of its annual precipitation, indicating that the non-monsoonal precipitation (45.2\%) (October-May) is also important. Therefore, factors controlling the isotopic variations in the nonmonsoonal precipitation are also discussed in order to provide more observational bases for better interpretation of the oxygen isotopic records in speleothems in the Asian monsoon region.

\section{Study area}

Nanjing is located on the lower reaches of the Yangtze River, surrounded by low hilly terrain with an average altitude of $26 \mathrm{~m}$ (Fig. 1a). The mean annual air temperature is $16^{\circ} \mathrm{C}$ and the average annual precipitation is $1106 \mathrm{~mm}$. Located close to the Tropic of Cancer, this area has a strong seasonal climate (Fig. 1b), with a distinct seasonal reversal of wind and alternation of dry and rainy periods.

In the summer (June-September), the study area is under the influence of both the East Asian summer monsoon and the Indian summer monsoon (Fig. 1a). With the onset of the summer monsoon, the warm and moist air masses from the south collide with cold air masses from the north in eastern China, forming a quasi-stationary rain belt known as Meiyu, also known as Baiu in Japan (Saito, 1995) and Changma in Korea (Oh et al., 1997). Meiyu starts in southern China between April and May, moving to the middle part of eastern China (Yangtze and Huai He river basins) between May and July, and to northern China between July and August, bringing with it consistent rainfall (Ding et al., 2007). The vapor trajectories indicate that moisture for summer precipi- tation at Nanjing mainly comes from the Bay of Bengal, the South China Sea, and the western Pacific (Fig. 2b). Heavy water isotopes are generally depleted (more negative $\delta^{18} \mathrm{O}$ or $\delta \mathrm{D}$ ) in summer precipitation at the monsoon region because of continuous upstream distillation processes of vapor starting from the remote oceanic moisture source region. In addition, the deuterium excess in summer precipitation (dexcess $\left.=\delta \mathrm{D}-8 \times \delta^{18} \mathrm{O}\right)($ Dansgaard, 1964) is also low due to limited kinetic evaporation over the oceanic moisture source region under high surface air humidity conditions.

After the retreat of the summer monsoon, the Mongolia High (also called Siberia-Mongolia High) starts to strengthen due to gradual cooling of Eurasia, indicating the switch from the summer monsoon to the winter/nonmonsoon season (October-May). In winter, air masses over Nanjing mainly originate from the northwest forced by the Mongolia High (Fig. 2d), and precipitation is generally derived from continental moisture sources and recycling, which tend to enrich heavy isotopes, leading to high isotopic values $\left(\delta^{18} \mathrm{O}, \delta \mathrm{D}\right.$ and d-excess).

\section{Methods and materials}

Using a rain gauge, precipitation samples were collected on days with precipitation greater than $0.1 \mathrm{~mm}$ from September 2011 to November 2014 with the exception of JanuaryApril 2013. This was carried out at the Station for Observing Regional Processes of the Earth System (SORPES) at Nanjing University (Ding et al., 2013). A narrow-mouth container with a diameter of $1 \mathrm{~cm}$ was used in order to minimize evaporation. Samples were collected as soon as possible after rainfall events and were immediately poured into $100 \mathrm{~mL}$ polyethylene bottles, which were then sealed and frozen for storage.

The $\delta^{18} \mathrm{O}$ and $\delta \mathrm{D}$ of these samples were simultaneously measured using a Picarro L2120-i wavelength scannedcavity ring down spectroscopy (WS-CRDS) system at the Key Laboratory of Coast and Island Development of the Ministry of Education, School of Geographic and Oceanographic Sciences, Nanjing University, China.

The stable isotopic ratio was calculated as

$\delta=\left[\frac{R_{\text {sample }}}{R_{\text {reference }}}-1\right] \times 1000 \%$,

where $R$ is the ratio of the composition of the heavier to lighter isotopes in water $\left({ }^{18} \mathrm{O} /{ }^{16} \mathrm{O}\right.$ for $\delta^{18} \mathrm{O}$, or $\mathrm{D} / \mathrm{H}$ for $\delta \mathrm{D})$, and the reference is the Vienna Standard Mean Ocean Water standard. Each sample was measured eight times. The maximum peak drift in $24 \mathrm{~h}$ of Picarro L2120-i is less than $0.6 \%$ for $\delta^{18} \mathrm{O}$ and $1.8 \%$ for $\delta \mathrm{D}$. In order to reduce the influence of instrument drift, internal water standard samples were inserted among the samples for measurements (one water standard sample for every seven samples). The first five measurements were discarded in order to eliminate the ef- 

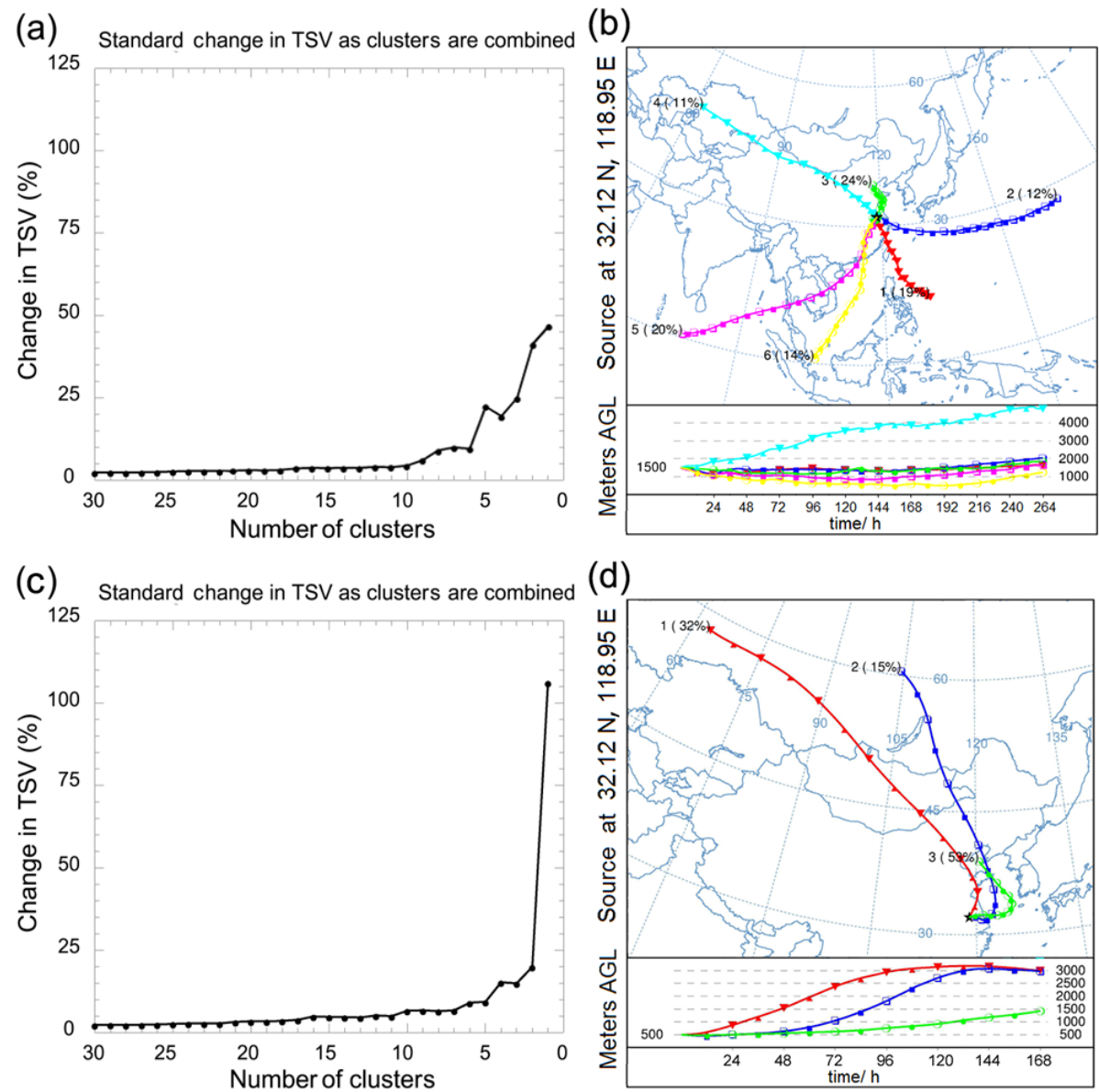

Figure 2. Change in TSV (total spatial variance) as clusters combined (left) and spatial distribution of vapor trajectories (right) for all precipitation events at Nanjing from September 2011 to November 2014: (a) and (b) are for the summer monsoon season (June-September), (c) and (d) are for the non-monsoon season (October-May). The vapor trajectories were simulated by the Hybrid Single-Particle Lagrangian Integrated Trajectory model (HYSPLIT). Vapor trajectories back to 11 days at $1500 \mathrm{~m}$ a.g.l. (above ground level) were calculated for the summer monsoon season as water vapor transport is usually concentrated in the middle and lower troposphere (Bershaw et al., 2012). The moisture transport paths back to 7 days at $500 \mathrm{~m}$ a.g.l. were determined for the non-monsoon season because of higher wind speed and lower condensation height in the non-monsoon season. The TSV was used to identify the optimum number of clusters.

fect of memory. The average of the last three measurements was calibrated based on the linear regression between the known isotopic values of our three internal water standards and their measured values. The calibrated values of samples were taken as the test results. The analytical uncertainty is less than $0.1 \%$ ofor $\delta^{18} \mathrm{O}$ and $0.5 \%$ for $\delta \mathrm{D}$. A quadratic error for $\mathrm{d}$-excess is less than $1.0 \%$, estimated by the uncertainties of $\delta^{18} \mathrm{O}$ and $\delta \mathrm{D}$.

In order to link precipitation stable isotopes with weather conditions, the daily meteorological data were obtained from the China Meteorological Data Sharing Service System, which included precipitation amount, surface air temperature, evaporation and relative humidity at Nanjing during the observation period. Additional data were obtained from National Centers for Environmental Prediction/National Center for Atmospheric Research (NCEP/NCAR) reanalysis data in order to identify changes of moisture source and vapor trans- port. They include the daily OLR, horizontal wind fields, and specific humidity, provided by the NOAA/ORA/ESRL PSD, Boulder, Colorado, USA, from their website at http: //www.esrl.noaa.gov/psd.

\section{Results}

\subsection{Seasonal variations of stable isotopes in precipitation}

Temporal variations of daily precipitation stable isotopes $\left(\delta^{18} \mathrm{O}, \delta \mathrm{D}\right.$ and d-excess), precipitation amount, and surface air temperature in Nanjing during the observation period are presented in Fig. 3. The isotopic data exhibits significant seasonal variations, with low values of the $\delta^{18} \mathrm{O}, \delta \mathrm{D}$ and $\mathrm{d}-$ excess in the summer monsoon season and high values in 


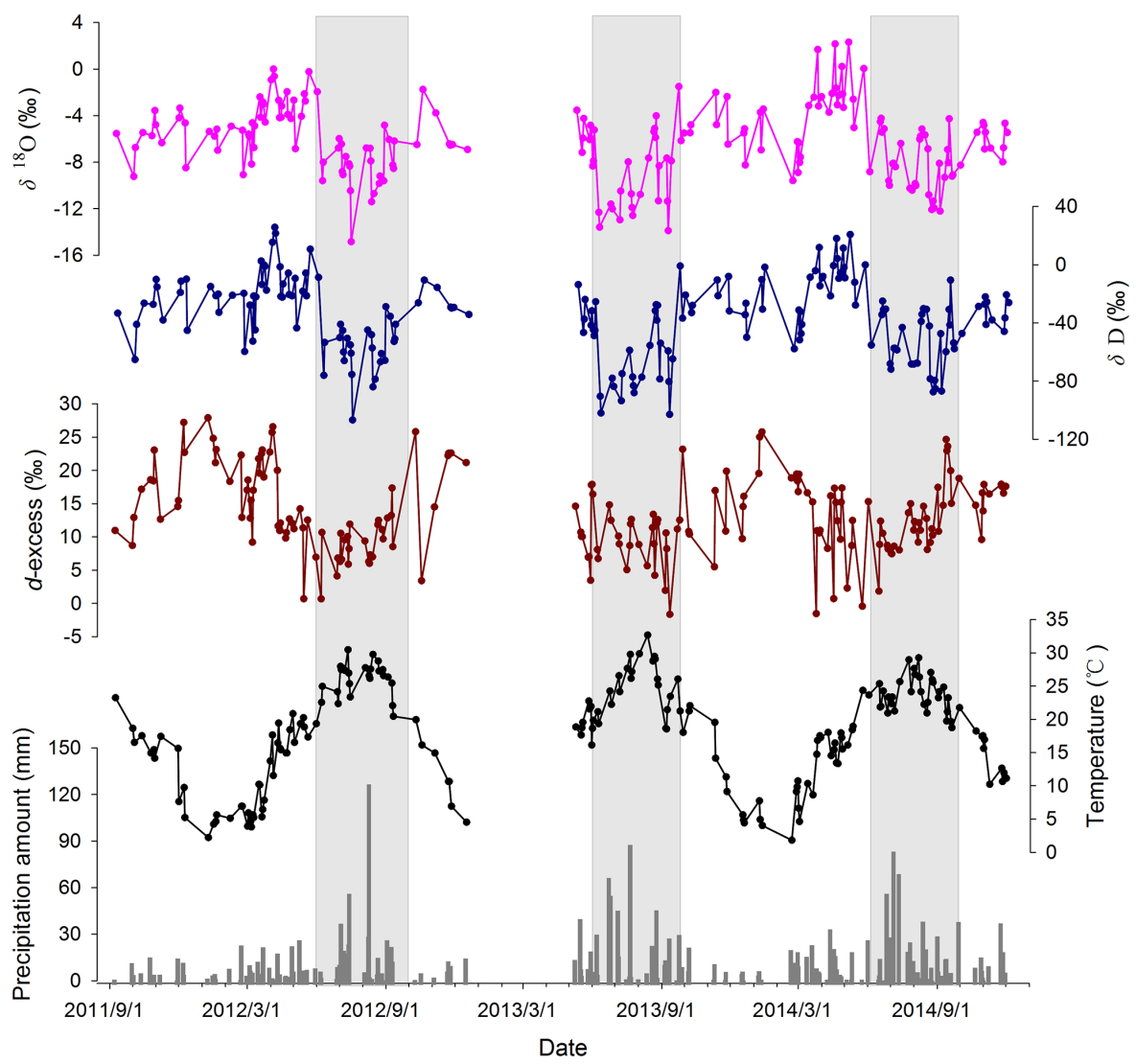

Figure 3. Temporal variations of daily precipitation $\delta^{18} \mathrm{O}, \delta \mathrm{D}$, d-excess, surface air temperature and precipitation amount in Nanjing from September 2011 to November 2014. The shaded areas represent the summer monsoon seasons (June-September). Data is missing from January to April 2013.

the non-monsoon season. The values in the summer monsoon season (the non-monsoon season) range from -14.8 to $-1.5 \%$ ( -9.5 to $2.3 \%$ ) for $\delta^{18} \mathrm{O}$, from -106.0 to $-0.3 \%$ o ( -59.0 to $26.2 \%$ ) for $\delta \mathrm{D}$, and from -1.4 to $24.8 \%$ o $(-1.3$ to $28.1 \%$ o) for d-excess. The precipitation-weighted mean isotopic value in the summer monsoon season (the nonmonsoon season) is $-9.1 \%$ ( $\left(-4.9 \%\right.$ ) for $\delta^{18} \mathrm{O},-61.8 \%$ o $(-23.4 \% o)$ for $\delta \mathrm{D}$, and $10.9 \%$ ( $15.5 \%$ ) for d-excess.

\section{2 $\delta^{18} \mathrm{O}$ variations in summer precipitation}

In 2012, after a sudden decrease on 6 June, the precipitation $\delta^{18} \mathrm{O}$ remained low, reaching a minimum $(-14.8 \%$ ) on $14 \mathrm{July}$. The $\delta^{18} \mathrm{O}$ values increased in early August, and decreased again in late August. In early September, $\delta^{18} \mathrm{O}$ in precipitation became enriched (Fig. 4b). In 2013, precipitation $\delta^{18} \mathrm{O}$ decreased suddenly on 7 June, then increased slowly until it peaked $(-4.0 \%$ ) on 22 August. The stable isotope composition was depleted in late August and reached a minimum $\left(-13.8 \%\right.$ o on 7 September. In late September, $\delta^{18} \mathrm{O}$ in precipitation was enriched (Fig. 4c). In 2014, $\delta^{18} \mathrm{O}$ in precipitation decreased on 1 June and slightly increased afterward until it was depleted again in July. It started to increase in early August. From late August to early September, $\delta^{18} \mathrm{O}$ in precipitation remained depleted but became enriched since late September (Fig. 4d).

We divided the summer into five distinct stages (Fig. 4), based on the temporal patterns of $\delta^{18} \mathrm{O}$ variations and the official designation of the Meiyu period in the study area. Stage 1 started with the sudden decrease in $\delta^{18} \mathrm{O}$ in early June, which is generally considered an indicator for the onset of the summer monsoon (e.g., Tian et al., 2001; Vuille et al., 2005; Yang et al., 2012). Stage 2 covered the Meiyu period. The start dates of Meiyu in 2012-2014 were 26, 23, and 25 June, respectively, according to the observations made by the Jiangsu Provincial Meteorological Bureau. Stage 3 was characterized by relatively high precipitation $\delta^{18} \mathrm{O}$, whereas in stage $4, \delta^{18} \mathrm{O}$ remained low. Stage 5 marked the return of $\delta^{18} \mathrm{O}$ values to the enriched state. The five stages are delineated in Fig. 4b-d.

\subsection{The amount effect of $\delta^{18} \mathrm{O}$ in summer precipitation}

The amount effect refers to the observed negative correlation between precipitation isotopic composition and precipitation amount (Dansgarrd, 1964). The most discussed mechanism 


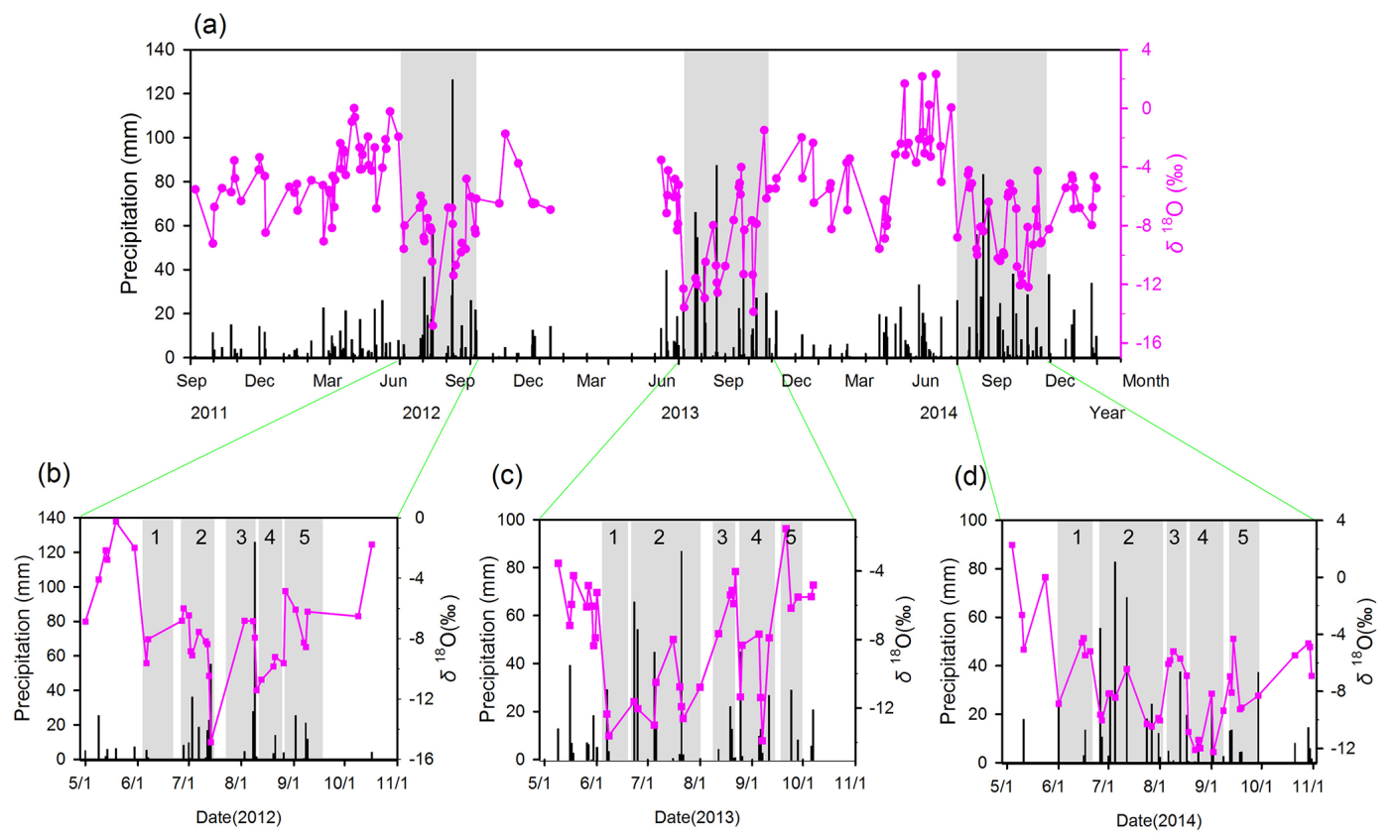

Figure 4. (a) Temporal variation of daily precipitation $\delta^{18} \mathrm{O}$ and precipitation amount from September 2011 to November 2014 (data is missing for $\delta^{18} \mathrm{O}$ from January to April 2013). (b-d) Temporal variations in daily precipitation $\delta^{18} \mathrm{O}$ and local precipitation amount from May to October in 2012 (b), 2013 (c), and 2014 (d). The shaded bars represent different stages. In (b) for 2012, stage 1: 3-20 June; stage 2: 27 June-14 July; stage 3: 20 July-9 August; stage 4: 10-26 August; and stage 5: 27 August-20 September. In (c) for 2013, stage 1: 7-20 June; stage 2: 23 June-1 August; stage 3: 12-22 August; stage 4: 25 August-11 September; and stage 5: 20-30 September. In (d) for 2014, stage 1: 1-20 June; stage 2: 26 June-1 August; stage 3: 6-17 August; stage 4: 18 August-8 September; and stage 5: 12-30 September.

for the amount effect is that high precipitation rates increase relative humidity, hence decreasing evaporation. As evaporation serves to enrich heavy isotopes, its reduction leads to more depleted precipitation isotopic signatures. Moreover, high relative humidity also inhibits re-evaporation of local surface water (lakes and streams) to feed back into the precipitation. As local surface water is usually more enriched in heavy isotopes, its diminished input also leads to more depleted precipitation isotopic composition. Here we investigated if the amount effect could be clearly observed from our data. We performed separate correlation analyses between precipitation $\delta^{18} \mathrm{O}$ and precipitation amount, relative humidity and the evaporation ratio defined as evaporation divided by precipitation (E/P) (Fig. 5). There was a weak negative correlation between precipitation $\delta^{18} \mathrm{O}$ and precipitation amount for 2013 (Fig. 5b). In addition, precipitation $\delta^{18} \mathrm{O}$ became more depleted with increased relative humidity (Fig. 5e) and decreased E / P ratio (Fig. 5h) for the same year. This seems to suggest that the amount effect was present in the 2013 data. However, no significant correlation was observed for the 2012 and 2014 data (Fig. 5a, c).

\subsection{The temperature effect of $\delta^{18} O$ in non-monsoonal precipitation}

In our study area, the $\delta^{18} \mathrm{O}$ values in non-monsoonal precipitation were primarily influenced by the temperature ef- fect, even though such effect is often dampened or even reversed in summer for southeastern Asia due to the summer monsoon influence (Araguás-Araguás et al., 1998). Our data clearly showed a significant positive correlation between the daily precipitation $\delta^{18} \mathrm{O}$ and surface air temperature in the non-monsoon seasons of the observation period, with a linear $T-\delta^{18} \mathrm{O}$ relationship: $\delta^{18} \mathrm{O}=0.16 T-6.56$ (Fig. 6).

\section{Discussion}

The ITCZ region is an important moisture source for precipitation in general and for monsoon precipitation in particular. In fact, the monsoon is often considered a manifestation of the intraseasonal migration of the ITCZ (Gadgil, 2003). To explore the possible influence of ITCZ intensity and position on $\delta^{18} \mathrm{O}$ in summer precipitation in Nanjing, a composite analysis of OLR was performed for each stage (Fig. 7). Low OLR values correspond to cold and high clouds associated with enhanced convection, and a negative relationship is generally observed between OLR and convection intensity (Wang et al., 1997). Therefore, a composite analysis of OLR could help establish the location and intensity of deep convections associated with the ITCZ, which serve as moisture sources for the monsoon precipitation in Nanjing. It was also necessary to establish the moisture transport magnitude and pathways for each stage in order to link the source regions 
(a)
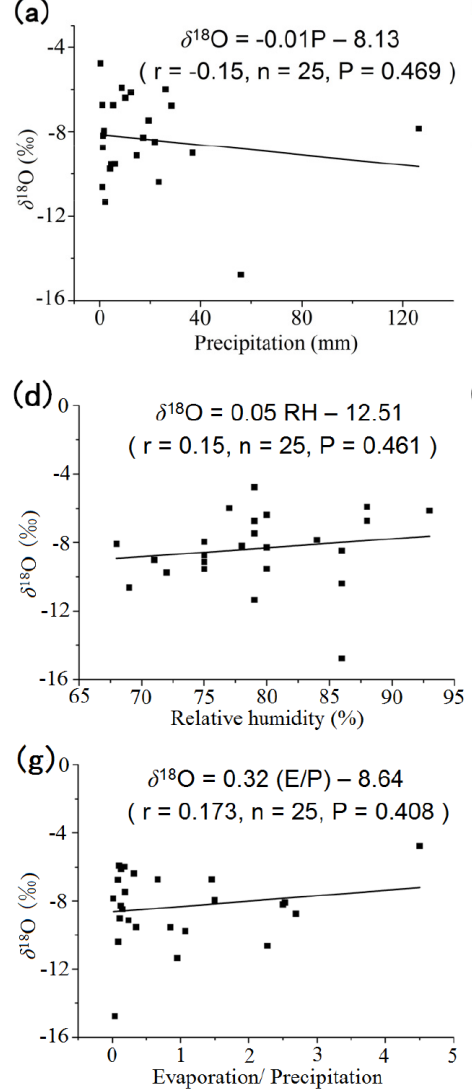

(b)

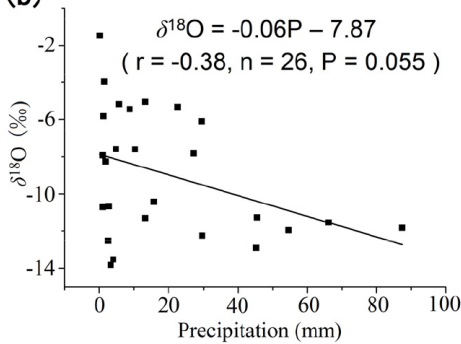

(c)

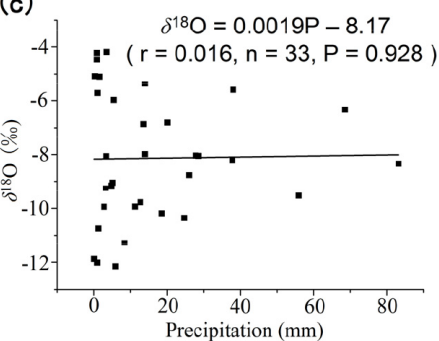

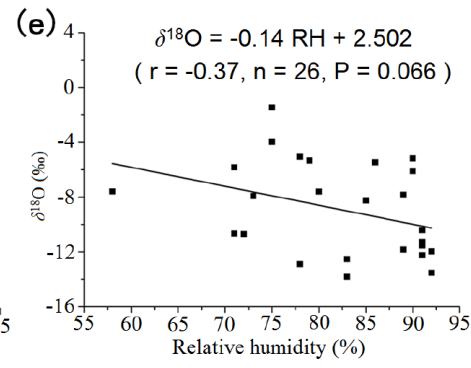
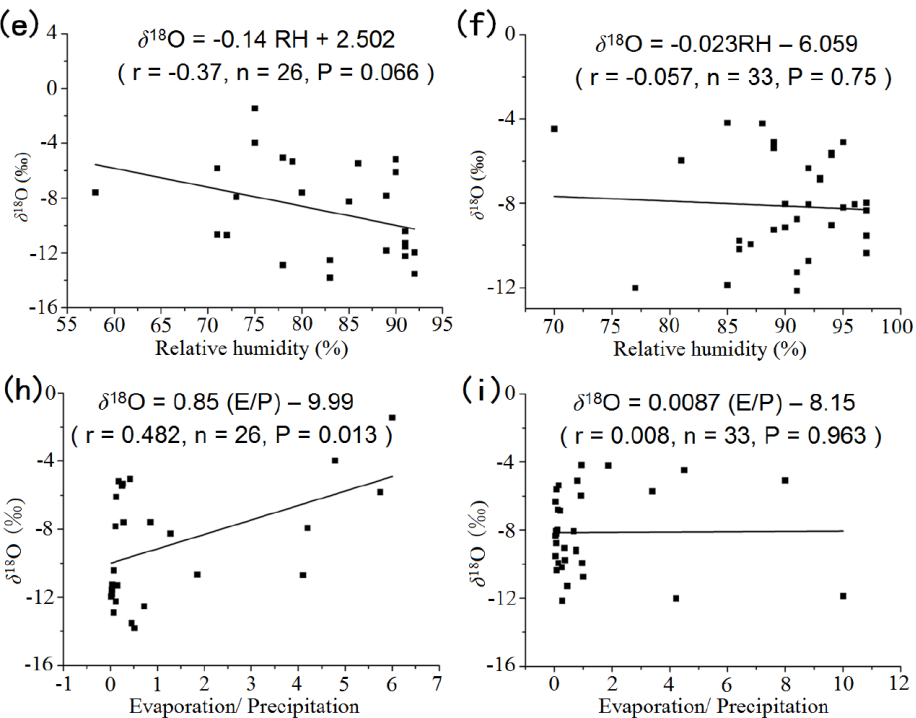

Figure 5. This figure shows (1) correlation between $\delta^{18} \mathrm{O}$ and precipitation amount in Nanjing from June to September for 2012 (a), 2013 (b) and 2014 (c); (2) correlation between $\delta^{18} \mathrm{O}$ and relative humidity in Nanjing from June to September for 2012 (d), 2013 (e) and 2014 (f); (3) correlation between $\delta^{18} \mathrm{O}$ and evaporation/precipitation (E/P) ratio in Nanjing from June to September for 2012 (g), 2013 (h) and 2014 (i). Linear regression lines, correlation coefficient $r$ and $p$ values are also shown.

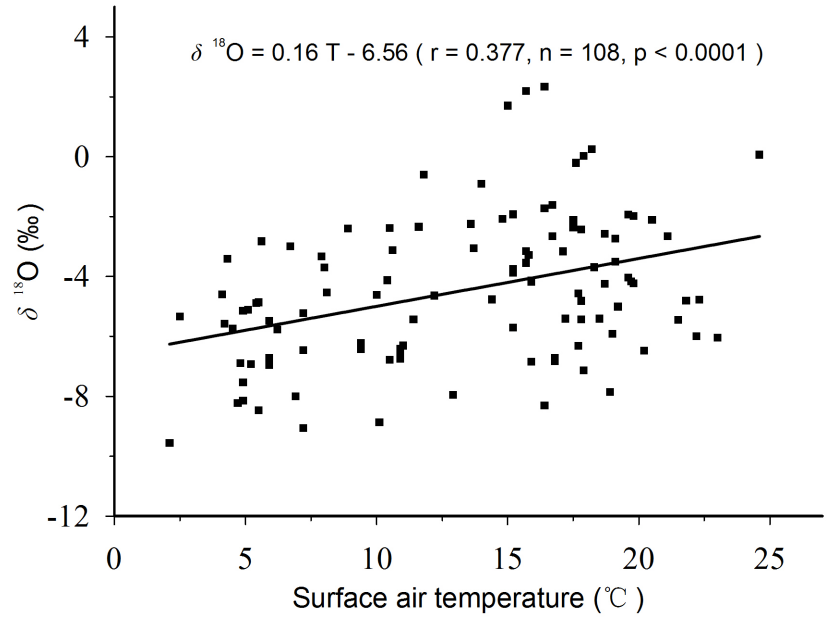

Figure 6. Correlation between daily precipitation $\delta^{18} \mathrm{O}$ and surface air temperature in the non-monsoon seasons of the observation period in Nanjing. Linear regression line, correlation coefficient $r$ and $p$ values are also shown. with our study area, as both could potentially influence the precipitation $\delta^{18} \mathrm{O}$. This was achieved by vertically integrating mean water vapor transport for each stage, using the daily NCEP/NCAR reanalysis data (Fig. 8). Water vapor transport was calculated as the horizontal wind field (zonal and meridional winds) multiplied by specific humidity, which was then integrated from the surface to the $300 \mathrm{hPa}$ level.

In stage 1 , the abrupt decrease of $\delta^{18} \mathrm{O}$ indicated the onset of the Asian summer monsoon, with strong ITCZ convections in the Bay of Bengal and the South China Sea (Fig. $7 \mathrm{a}, \mathrm{f}, \mathrm{k}$ ) and the delivery of moisture from both regions (Fig. 8a, f, k). The isotope fractionation that occurred during the strong convection and the transport process lightened the stable isotopes in water vapor, resulting in the abrupt decrease of $\delta^{18} \mathrm{O}$ in precipitation in Nanjing.

In stage 2, the ITCZ intensity and location in $2012 \mathrm{did}$ not change significantly from stage 1 (Fig. $7 \mathrm{~b}$ ), and $\delta^{18} \mathrm{O}$ remained low. The extreme negative $\delta^{18} \mathrm{O}$ on 14 July was due to the continuous local rainfall from 12 to 14 July, further depleting $\delta^{18} \mathrm{O}$ in precipitation. In 2013, the ITCZ intensity did not change much in the Bay of Bengal but decreased signif- 

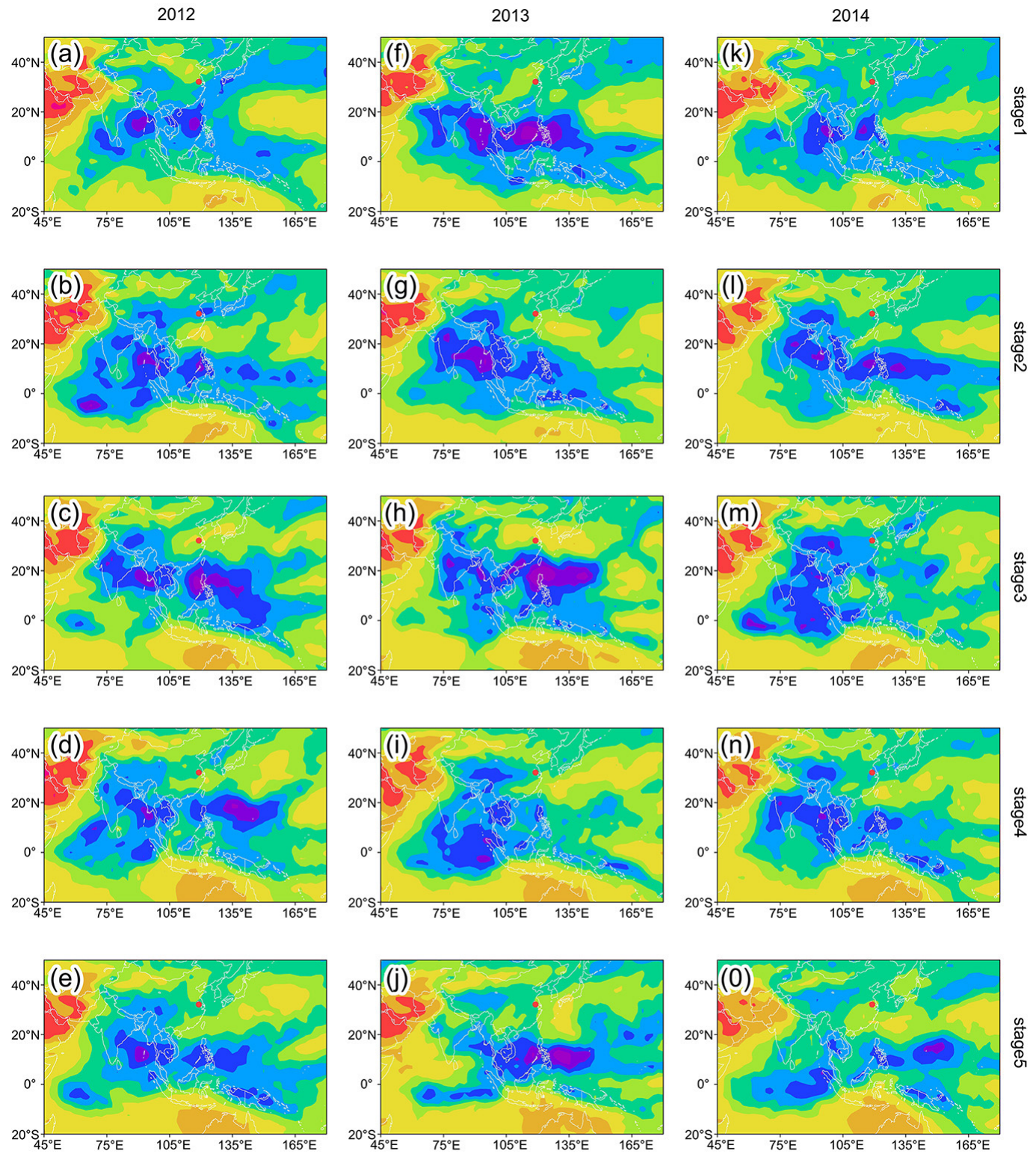

\section{$\begin{array}{lllllllll}160 & 180 & 200 & 220 & 240 & 260 & 280 & 300 & 320\end{array}$}

Outgoing longwave radiation $\left(\mathrm{W} \mathrm{m}^{-2}\right)$

Figure 7. Composite results for average OLR $\left(\mathrm{W} \mathrm{m}^{-2}\right)$ for stages $1-5$ in $2012(\mathbf{a}-\mathbf{e}), 2013(\mathbf{f}-\mathbf{j})$ and 2014 (k-o). The convective activity is indicated by low values in OLR. Daily OLR data at $2.5^{\circ} \times 2.5^{\circ}$ resolution were used. The study site of Nanjing is marked by the red dot.

icantly in the South China Sea and the low-latitude western Pacific Ocean (Fig. 7g). Weak convection reduced the rainout effect and hence increased $\delta^{18} \mathrm{O}$ in precipitation. In 2014 the ITCZ intensity increased in the South China Sea and the low-latitude western Pacific Ocean, but it did not change significantly in the Bay of Bengal (Fig. 71). At this stage, as the meridional water vapor transport to the north from the South China Sea increased (Fig. 8b, g, 1), changes in convective activity in the South China Sea had a stronger influence on $\delta^{18} \mathrm{O}$ in the study area's precipitation. Strong convection in the South China Sea enhanced the rainout effect, resulting in depleted $\delta^{18} \mathrm{O}$ in precipitation in Nanjing.

In stage 3, the ITCZ intensity decreased in the Bay of Bengal in both 2012 and 2013 but increased in the South China Sea and the low-latitude western Pacific Ocean. The center of strong convection propagated northward (Fig. 7c, h). Water vapor mainly originated from the South China Sea and the low-latitude western Pacific Ocean (Fig. 8c, h) for this 

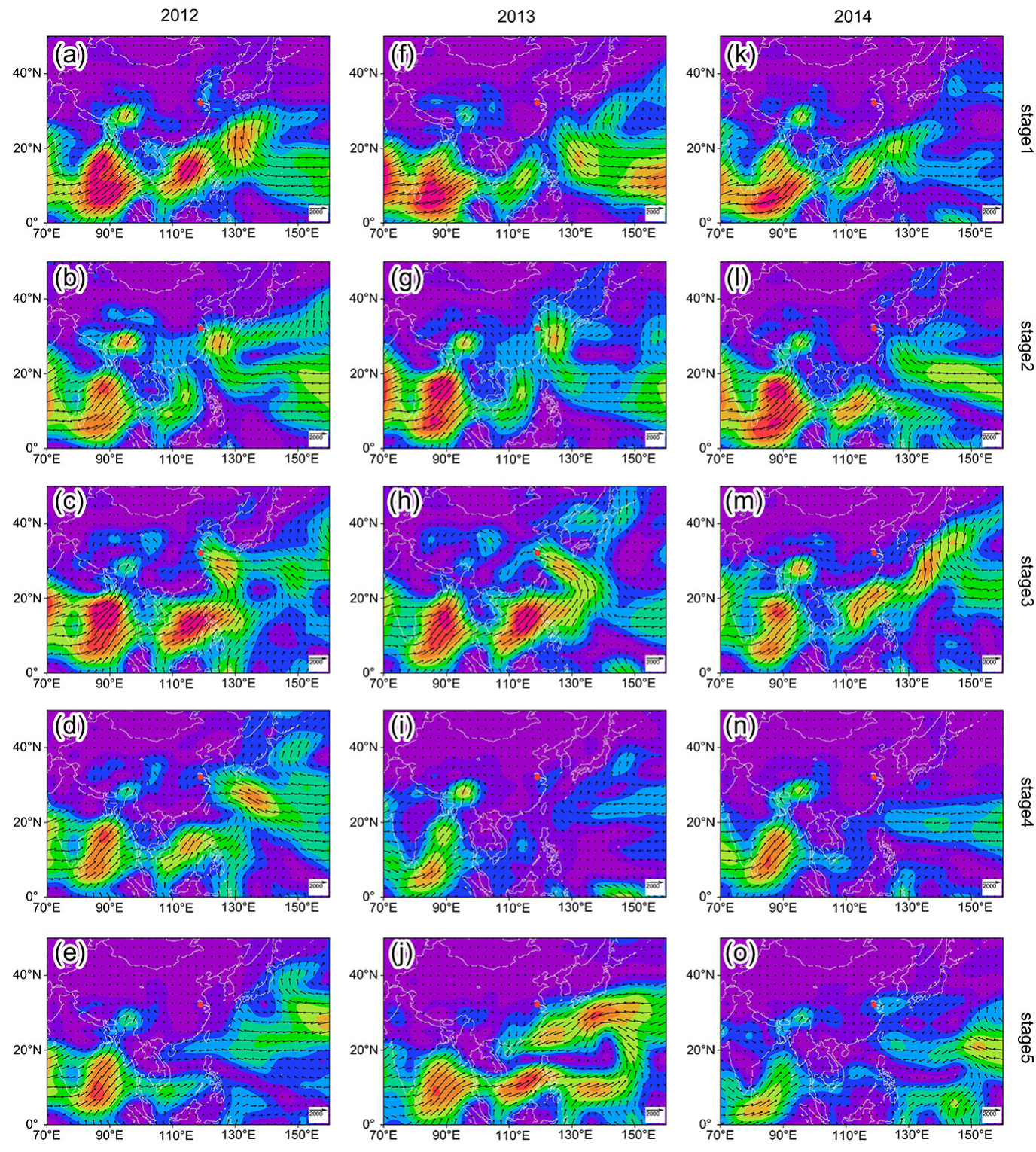

200400600800100012001400160018002000
Mean water vapor transport $\left(\mathrm{g} \mathrm{cm}^{-1} \mathrm{~s}^{-1}\right)$

Figure 8. Vertically integrated mean water vapor transport $\left(\mathrm{g} \mathrm{cm}^{-1} \mathrm{~s}^{-1}\right)$ for stages $1-5$ in 2012 (a-e), 2013 (f-j) and 2014 (k-o). Different colors indicate the magnitude of the moisture flux vector. The study site of Nanjing is marked by the red dot.

stage. The relatively shorter transport distance resulted in higher $\delta^{18} \mathrm{O}$ values in precipitation. In 2014, the ITCZ intensity was relatively low in the South China Sea and the lowlatitude western Pacific Ocean (Fig. 7m). The water vapor came mainly from the adjacent seas (Fig. $8 \mathrm{~m}$ ). As a result, the relatively weak convection in the area and short transport distance enriched $\delta^{18} \mathrm{O}$ in precipitation in Nanjing.

Stage 4 covered the late monsoon season. In 2012, in addition to increased convection strength in the western Pacific Ocean, the strong convective center also moved eastward
(Fig. 7d), increasing the water transport distance to Nanjing. Both of these changes acted to deplete $\delta^{18} \mathrm{O}$ in precipitation. Moreover, the moisture transport suggested that vapor from the Bay of Bengal was also transported to Nanjing (Fig. 8d). The strong convection in the Bay of Bengal and its long distance from the study site contributed to further deplete $\delta^{18} \mathrm{O}$ in precipitation. In 2013 and 2014, the ITCZ intensity in the South China Sea and the western Pacific was relatively weak (Fig. 7i, n). However, both the moisture transport from the Bay of Bengal (Fig. 8i, n) and the convective activity in the 
Bay of Bengal was strong (Fig. 7i, n). In addition, the strong convective center in the Bay of Bengal moves southward in stage 4 of 2013 (Fig. 7i) resulting in longer distance transport to Nanjing. The combination of these factors depleted the isotopic composition of precipitation in this stage for both 2013 and 2014. This is consistent with the time series of $\delta^{18} \mathrm{O}$ in precipitation, which showed a clear trend of decreasing $\delta^{18} \mathrm{O}$ values during the late monsoon period, while rainfall peaked earlier in the season. The depleted $\delta^{18} \mathrm{O}$ values late in the monsoon season were also observed in the other monsoon areas. Pang et al. (2006) suggested that the low $\delta^{18} \mathrm{O}$ values were caused by the recycling of monsoon precipitation late in the monsoon season. Breitenbach et al. (2010), on the other hand, argued that the Bay of Bengal freshwater plume, consisting of isotopically depleted rainwater and snowmelt water, diluted the Bay of Bengal surface water $\delta^{18} \mathrm{O}$ pool late in the monsoon season. This contributed to the depleted $\delta^{18} \mathrm{O}$ in precipitation. Our results suggest that the depleted precipitation $\delta^{18} \mathrm{O}$ late in the monsoon season could result from the combination of increased convective activities and transport distance due to the retreat of the ITCZ southward in the Bay of Bengal.

In stage 5, the Asian summer monsoon retreated and water vapor from the inland areas with a high stable isotopic composition was transported to Nanjing (Fig. 8e, j, o), enriching the $\delta^{18} \mathrm{O}$ in precipitation. It is worth noting that the ITCZ intensity in the South China Sea and the low-latitude western Pacific Ocean strengthened in stage 5 of 2013 because of the super-typhoon Usagi (Fig. 7j). However, Nanjing was not affected due to its location at the edge of the typhoon. At the time, the moisture in Nanjing came mainly from the northern inland areas and the adjacent seas in the northeast (Fig. 8e, j, o). Therefore, the stable isotopic composition of precipitation remained enriched.

The above observations seem to suggest that summer precipitation $\delta^{18} \mathrm{O}$ in Nanjing were closely related to changes in moisture source and convective activity within moisture source regions. In order to further explore this relationship quantitatively, we performed a time-lagged spatial correlation analysis between precipitation $\delta^{18} \mathrm{O}$ in Nanjing and the daily OLR time series. Several patterns emerged from this analysis. For stage 1 and 4, the strongest positive correlation between $\delta^{18} \mathrm{O}$ and OLR in the Bay of Bengal occurred at 13 and 14 days before the rainfall (Fig. 9a, b). This supports the conclusion of previous studies that convective processes could have integrated impacts on water vapor over several days preceding precipitation events (Tremoy et al., 2012; Gao et al., 2013). For stage 2, our analysis showed the strongest positive correlation between $\delta^{18} \mathrm{O}$ and the OLR in the South China Sea at 5 and 6 days preceding the rainfall (Fig. 9c, d). This supports the significant influence of convective intensity in the South China Sea on $\delta^{18} \mathrm{O}$ in precipitation in Nanjing at stage 2. As this stage covered the Meiyu period, this result is largely in agreement with previous studies, which indicate that moisture for Meiyu precipitation mainly
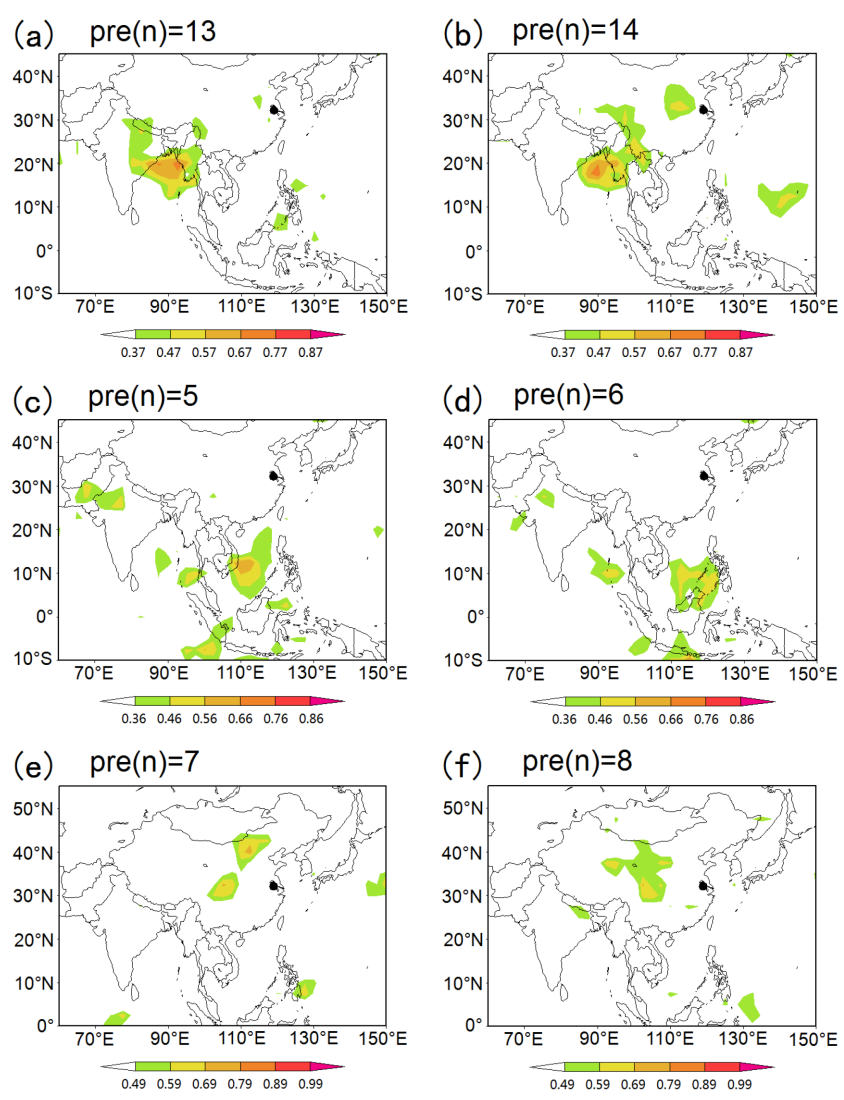

Figure 9. Spatial correlation between daily $\delta^{18} \mathrm{O}$ in precipitation and OLR at $n$ days prior to the rainfall date. Spatial correlation between $\delta^{18} \mathrm{O}$ in precipitation and OLR at 13 days (a) and 14 days (b) prior to the rainfall date for stages 1 and 4 . Spatial correlation between $\delta^{18} \mathrm{O}$ in precipitation and OLR at 5 days (c) and 6 days (d) prior to the rainfall date for stage 2. Spatial correlation between $\delta^{18} \mathrm{O}$ in precipitation and OLR at 7 days (e) and 8 days (f) prior to the rainfall date for stage 5 . For all maps, only areas with correlations significant at the 0.05 level are shown. The study site Nanjing is marked with a black dot.

comes from the South China Sea (Simmonds et al., 1999; Ding et al., 2007). For stage 5, the strongest positive correlation between daily $\delta^{18} \mathrm{O}$ in precipitation and OLR in the inland areas to the north and west was observed at 7 and 8 days before the rainfall (Fig. 9e, f), suggesting that inland vapor contributed to $\delta^{18} \mathrm{O}$ in precipitation after the monsoon withdrew. However, no significant correlation between $\delta^{18} \mathrm{O}$ and OLR was found for stage 3 . This could partially be attributed to the shifts of the ITCZ location northward and eastward in 2012 and 2013 (Fig. 7c, h), reducing the vapor transport distance (Fig. 8c, h). This could have played a more important role in determining the $\delta^{18} \mathrm{O}$ values in precipitation in Nanjing than convective intensity.

Our results suggest that changes in moisture source and the upstream convective activity over the tropical regions of the Bay of Bengal, the South China Sea and the western Pacific have an important impact on the daily isotopic 
composition of summer precipitation in Nanjing. Strong distillation processes during intense convective activity would increase the rainout of heavy isotopes upstream, hence depleting the isotopic composition in precipitation downstream and vice versa. Therefore, the daily isotopic composition in summer precipitation downstream of the moisture sources in the tropics could be determined mainly by changes of the isotopic composition of atmospheric vapor in the upstream source region rather than the precipitation amount on site. It should be noted that although such effects as the changes in moisture source and the upstream rainout on stable isotopes in precipitation could clearly be observed on the intraseasonal timescale, as discussed above, they may not be significant on inter-annual to decadal timescales because of insufficient changes in moisture source and the upstream rainout when averaged at these timescales. Nevertheless, these effects could be important on longer timescales (centennial to orbital timescales), such as the glacial-interglacial timescale, when moisture source locations and the upstream rainout processes could vary remarkably. Pausata et al. (2011) used a climate model with an embedded oxygen-isotope model to simulate a Heinrich event and found that the variations of stalagmite $\delta^{18} \mathrm{O}$ values in southern China mainly reflected $\delta^{18} \mathrm{O}$ changes in the source vapor from the Indian Ocean rather than local precipitation amount. Liu et al. (2015) also indicated that the stalagmite $\delta^{18} \mathrm{O}$ records during the Holocene from the East Asian summer monsoon region are essentially a signal of the isotopic composition of precipitation, which is largely determined by the upstream depletion mechanism over the Indian Ocean and the Indian monsoon region.

Although changes in moisture source and upstream rainout effect seem to be the main controlling factors for the intra-seasonal isotopic variations of precipitation at Nanjing during the summer monsoon season, a correlation between the $\delta^{18} \mathrm{O}$ and precipitation amount did exist in the summer of 2013 (Fig. 5b). To examine this further, we downloaded data from the Global Network for Isotopes in Precipitation (GNIP) (http://isohis.iaea.org/gnip.asp) for Nanjing, covering the summers of 1987-1992, and found a weak but statistically significant negative correlation between the monthly isotopic composition $\left(\delta^{18} \mathrm{O}\right.$ or $\left.\delta \mathrm{D}\right)$ and precipitation amount. This seems to suggest that the amount effect could still play an important role, particularly at the timescales when precipitation varied greatly, such as the glacial-interglacial climate cycles. In addition, there is likely considerable amount of local evapotranspiration in the Asian monsoon region because of high vegetation cover under humid monsoon climate conditions. How local evapotranspiration affects the summer precipitation $\delta^{18} \mathrm{O}$ is still unclear and requires further study.

The linear slope between the daily surface air temperature and $\delta^{18} \mathrm{O}$ in non-monsoonal precipitation in Nanjing is $0.16 \% / /{ }^{\circ} \mathrm{C}$ based on our observations. This is largely consistent with the slope $\left(0.20 \%{ }^{\circ} \mathrm{C}\right)$ calculated from the GNIP Nanjing station data. This confirms the temperature effect of stable isotopes in the non-monsoon season. By compar- ison, the correlation between surface air temperature and non-monsoonal precipitation $\delta^{18} \mathrm{O}$ of Nanjing is weaker than those observed in high latitudes. This may be caused by the switch of moisture source from the nearby offshore seas to the remote inland regions of Eurasia (Fig. 2d). In addition, the relatively dry climate condition in the non-monsoon season could increase the potential re-evaporation of precipitation and affect the isotopic composition of precipitation during its falling. This could also contribute to the weak temperature effect on stable isotopes. Regardless, the considerable precipitation amount in the non-monsoon season highlights the importance of the temperature effect for interpretation of stable isotope records in speleothems from the monsoon region. Some studies demonstrated that winter temperatures in eastern China were dominated by the East Asian winter monsoon associated with the Mongolia High (Guo, 1994; Liu et al., 2011).

Based on the above analysis, the isotopic composition of precipitation preserved in speleothems in the East Asian monsoon region is likely controlled by both the East Asian summer and winter monsoon processes. Indeed, Clemens et al. (2010) suggested that the timing of light $\delta^{18} \mathrm{O}$ peaks in speleothems from southeastern China on the orbital timescale were controlled by both strong summer monsoons and winter temperature changes. Other studies suggest that the oxygen isotope records in Chinese speleothems indicate changes in the ratio of summer to winter precipitation (Wang et al., 2001, 2008; Yuan et al., 2004; Dykoski et al., 2005; Kelly et al., 2006; Zhang et al., 2008; Cheng et al., 2009). However, this inference is not backed up by any physical mechanisms, as various factors affecting stable isotopes of precipitation were not considered. Indeed, no correlation was found between the annual mean weighted-precipitation $\delta^{18} \mathrm{O}$ and the ratio of summer to winter precipitation in the combined data from our observation (2012-2014) and the GNIP data (1987-1992). Years with more than 2 months of missing data were excluded from the analysis.

In summary, when interpreting the oxygen isotopic records in speleothems in the Asian monsoon region at longer timescales such as the glacial-interglacial climate cycles, both the upstream rainout effect on stable isotopes related to changes in the Asian summer monsoon and the temperature effect associated with winter monsoon should be considered. Both effects could be evaluated by present-day observation and historical simulations of water stable isotopes in the general circulation models (Risi et al., 2010; Werner et al., 2011).

\section{Conclusions}

We found that the intra-seasonal variations of $\delta^{18} \mathrm{O}$ of precipitation in Nanjing during summer were closely related to changes in the location and convection intensity in moisture sources. At the onset of the summer monsoon (stage 1), va- 
por to our study site was mainly transported from the Bay of Bengal, where the strong convection in the source area and its relatively long distance from our study area acted to decrease $\delta^{18} \mathrm{O}$ in precipitation in Nanjing. During the Meiyu period (stage 2), water vapor came mainly from the South China Sea, and changes in ITCZ intensity in the South China Sea led to the variability of $\delta^{18} \mathrm{O}$ in precipitation in Nanjing. The northward propagation of the ITCZ during the mid-monsoon season (stage 3 ) reduced the vapor transport distance, resulting in relatively enriched $\delta^{18} \mathrm{O}$. During the late monsoon period (stage 4), the ITCZ retreated to the Bay of Bengal. The strong convection and relatively long-distance vapor transport again led to depleted $\delta^{18} \mathrm{O}$ values in precipitation in Nanjing. Finally, when the monsoon withdrew (stage 5), vapor from the north and west inland areas contributed to the enriched $\delta^{18} \mathrm{O}$. The results indicate that the changes in the ITCZ location and intensity are major factors affecting the stable isotopes in summer precipitation in Nanjing. Therefore, the stable isotopes in precipitation could signal a shift of moisture source regions and ITCZ over the course of the monsoon season. Our analyses suggest that changes in moisture sources and upstream rainout effect should be taken into account when interpreting the stable isotopic composition of speleothems in the Asian monsoon region. However, the temperature effect of stable isotopes in precipitation during the non-monsoon season is also important because almost half of the annual precipitation occurs in the non-monsoon season.

Acknowledgements. We thank the NOAA Air Resources Laboratory (ARL) for providing the HYSPLIT model used in this study. This work was supported by the Natural Science Foundation of China (41330526, 41171052 and 41321062), the Natural Science Foundation of Jiangsu Province (BK20151387), and the Priority Academic Program Development (PAPD) of Jiangsu Higher Education Institutions.

Edited by: L. Wang

\section{References}

Ananthakrishnan, R., Pathan, J. M., and Aralikatti, S. S.: On the northward advance of the ITCZ and the onset of the southwest monsoon rains over the southeast Bay of Bengal, Int. J. Climatol., 1,153-165, 1981.

Araguás-Araguás, L., Froehlich, K., and Rozanski, K.: Stable isotope composition of precipitation over southeast Asia, J. Geophys. Res., 103, 28721-28742, 1998.

Bershaw, J., Penny, S. M., and Garzione, C. N.: Stable isotopes of modern water across the Himalaya and eastern Tibetan Plateau: implications for estimates of paleoelevation and paleoclimate, J. Geophys. Res., 117, D02110, doi:10.1029/2011JD016132, 2012.

Breitenbach, S. F. M., Adkins, J. F., Meyer, H., Marwan, N., Kumar, K. K., and Haug, G. H.: Strong influence of water vapor source dynamics on stable isotopes in precipitation observed in South- ern Meghalaya, NE India, Earth. Planet. Sc. Lett., 292, 212-220, 2010.

Cai, Y. J., Tan, L. C., Cheng, H., An, Z. S. Edwards, R. L., Kelly, M. J., Kong, X. G., and Wang, X. F.: The variation of summer monsoon precipitation in central China since the last deglaciation, Earth Planet. Sc. Lett., 291, 21-31, 2010.

Cheng, H., Edwards, R. L., Broecker, W. S., Denton, G. H., Kong, X. G., Wang, Y. J., Zhang, R., and Wang, X. F.: Ice Age Terminations, Science, 326, 248-252, 2009.

Clemens, S. C., Prell, W. L., and Sun, Y.: Orbital-scale timing and mechanisms driving Late Pleistocene Indo-Asian summer monsoons: Reinterpreting cave speleothem $\delta^{18} \mathrm{O}$, Paleoceanography, 25, PA4207, doi:10.1029/2010PA001926, 2010.

Conroy, J. L., Cobb, K. M., and Noone, D.: Comparison of precipitation isotope variability across the tropical Pacific in observations and SWING2 model simulations, J. Geophys. Res., 118, 5867-5892, 2013.

Cruz, F. W., Burns, S. J., Karmann, I., Sharp, W. D., Vuille, M., Cardoso, A. O., Ferrari, J. A., Dias, P. L. S., and Viana Jr., O.: Insolation-driven changes in atmospheric circulation over the past 116000 years in subtropical Brazil, Nature, 434, 63-66, 2005.

Cruz, F. W., Vuille, M., Burns, S. J., Wang, X. F., Cheng, H., Werner, M., Edwards, R. L., Karmann, I., Auler, A. S., and Nguyen, H.: Orbitally driven east-west antiphasing of South American precipitation, Nat. Geosci., 2, 210-214, 2009.

Dansgarrd, W.: Stable isotopes in precipitation, Tellus, 16, 436-468, 1964.

Dayem, K. E., Molnar, P., Battisti, D. S., and Roe, G. H.: Lessons learned from oxygen isotopes in modern precipitation applied to interpretation of speleothem records of paleoclimate from eastern Asia, Earth Planet. Sc. Lett., 295, 219-230, 2010.

Ding, A. J., Fu, C. B., Yang, X. Q., Sun, J. N., Zheng, L. F., Xie, Y. N., Herrmann, E., Nie, W., Petäjä, T., Kerminen, V.-M., and Kulmala, M.: Ozone and fine particle in the western Yangtze River Delta: an overview of $1 \mathrm{yr}$ data at the SORPES station, Atmos. Chem. Phys., 13, 5813-5830, doi:10.5194/acp-13-58132013, 2013.

Ding, Y. H.: The variability of the Asian summer monsoon, J. Meteor. Soc. Jpn, 85B, 21-54, 2007.

Ding, Y. H., Liu, J. J., Sun, Y., Liu, Y. J., He, J. H., and Song. Y. F.: A Study of the Synoptic-Climatology of the Meiyu System in East Asia, Chinese Journal of Atmospheric Sciences (in Chinese), 31, 1082-1100, 2007.

Dykoski, C. A., Edwards, R. L., Cheng, H., Yuan, D. X., Cai, Y. J., Zhang, M. L., Lin, Y. S., Qing, J. M., An, Z. S., and Revenaugh, J.: A high-resolution, absolute-dated Holocene and deglacial Asian monsoon record from Dongge Cave, China, Earth Planet. Sc. Lett., 233, 71-86, 2005.

Gadgil, S.: The Indian monsoon and its variability, Annu. Rev. Earth Pl. Sc., 31, 429-467, 2003.

Gao, J., Delmotte, V. M., Risi, C., He, Y., and Yao, T. D.: What controls precipitation $\delta^{18} \mathrm{O}$ in the southern Tibetan Plateau at seasonal and intra-seasonal scales? A case study at Lhasa and Nyalam, Tellus, 65, 1-14, 2013.

Gu, G. J. and Zhang, C. D.: Cloud components of the Intertropical Convergence Zone, J. Geophys. Res., 107, 4565, doi:10.1029/2002JD002089, 2002. 
Guo, Q.: Relationship between the variations of East Asian winter monsoon and temperature anomalies in China, Quarterly Journal of Applied Meteorology, 5, 218-225, 1994 (in Chinese with English abstract).

He, Y., Risi, C., Gao, J., Masson-Delmotte, V., Yao, T., Lai, C., Ding, Y., Worden, J., Frankenberg, C., Chepfer, H., and Cesana, G.: Impact of atmospheric convection on south Tibet summer precipitation isotopologue composition using a combination of in situ measurements, satellite data, and atmospheric general circulation modeling, J. Geophys. Res.-Atmos., 120, 3852-3871, doi:10.1002/2014JD022180, 2015.

Hu, C. Y., Henderson, G. M., Huang, J. H., Xie, S. C., Sun, Y., and Johnson, K. R.: Quantification of Holocene Asian monsoon rainfall from spatially separated cave records, Earth Planet. Sc. Lett., 266, 221-232, 2008.

Kelly, M. J., Edwards, R. L., Cheng, H., Yuan, D. X., Cai, Y. J., Zhang, M. L., Lin, Y. S., and An, Z. S.: High resolution characterization of the Asian Monsoon between 146,000 and 99,000 years B.P. from Dongge Cave, China and global correlation of events surrounding Termination II, Palaeogeogr. Palaeocl., 236, 20-38, 2006.

Kurita, N.: Water isotopic variability in response to mesoscale convective system over the tropical ocean, J. Geophys. Res., 118, 10376-10390, 2013.

Kurita, N., Ichiyanagi, K., Matsumoto, J., Yamanaka, M. D., and Ohata, T.: The relationship between the isotopic content of precipitation and the precipitation amount in tropical regions, J. Geochem. Explor., 102, 113-122, 2009.

Lawrence, J. R., Gedzelman, S. D., Dexheimer, D., Cho, H. K., Carrie, G. D., Gasparini, R., Anderson, C. R., Bowman, K. P., and Biggerstaff, M. I.: Stable isotopic composition of water vapor in the tropics, J. Geophys. Res., 109, D06115, doi:10.1029/2003JD004046, 2004.

Lekshmy, P. R., Midhum, M., Ramesh, R., and Jani, R. A.: ${ }^{18} \mathrm{O}$ depletion in monsoon rain relates to large scale organized convection rather than the amount of rainfall, Scientific Reports, 4, 5661, doi:10.1038/srep05661, 2014.

Liu, J., Chen, J., Zhang, X., Li, Y., Rao, Z., and Chen, F.: Holocene East Asian summer monsoon records in northern China and their inconsistency with Chinese stalagmite $\delta^{18} \mathrm{O}$ records, Earth-Sci. Rev., 148, 194-208, 2015.

Liu, Q., Wang, P., Xu, X., Zhi, H., and Sun, X.: A group of circulation indices of Mongolia High and analysis of its relationship with simultaneous anomaly in the climate of China, J. Trop. Meteorol., 27, 889-898, 2011 (in Chinese with English abstract).

Moerman, J. W., Cobb, K. M., Adkins, J. F., Sodemann, H., Clark, B., and Tuen, A. A.: Diurnal to interannual rainfall variations in northern Borneo driven by regional hydrology, Earth. Planet. Sc. Lett., 369, 108-119, 2013.

Oh, T. H., Kwon, W. T., and Ryoo, S. B.: Review of the researches on Changma and future observational study (KORMEX), Adv. Atmos. Sci., 14, 207-222, 1997.

Pang, H., Hou, S., Kaspari, S., and Mayewski, P. A.: Influence of regional precipitation patterns on stable isotopes in ice cores from the central Himalayas, The Cryosphere, 8, 289-301, doi:10.5194/tc-8-289-2014, 2014.

Pang, H. X., He, Y. Q., Lu, A. G., Zhao, J. D., Ning, B. Y., Yuan, L. L., and Song, B.: Synoptic-scale variation of $\delta^{18} \mathrm{O}$ in summer monsoon rainfall at Lijiang, China, Chinese Sci. Bull., 51, 2897 2904, 2006.

Partin, J. W., Cobb, K. M., Adkins, J. F., Clark, B., and Fernandez, D. P.: Millennial-scale trends in west Pacific warm pool hydrology since the Last Glacial Maximum, Nature, 449, 452-455, 2007.

Paulsen, D. E., Li, H. C., and Ku, T. L.: Climate variability in central China over the last 1270 years revealed by high-resolution stalagmite records, Quaternary. Sci. Rev., 22, 691-701, 2003.

Pausata, F. S., Battisti, D. S., Nisancioglu, K. H., and Bitz, C. M.: Chinese stalagmite $\delta^{18} \mathrm{O}$ controlled by changes in the Indian monsoon during a simulated Heinrich event, Nat. Geosci., 4, 474-480, 2011.

Peng, T. R., Wang, C. H., Huang, C. C., Fei, L. Y., Chen, C. T. A., and Hwong, J. L.: Stable isotopic characteristic of Taiwan's precipitation: A case study of western Pacific monsoon region, Earth Planet. Sc. Lett., 289, 357-366, 2010.

Risi, C., Bony, S., Vimeux, F., and Jouzel, J.: Water-stable isotopes in the LMDZ4 general circulation model: Model evaluation for present-day and past climates and applications to climatic interpretations of tropical isotopic records, J. Geophy. Res., 115, D12118, doi:10.1029/2009JD013255, 2010.

Saito, N.: Quasi-stationary waves in mid-latitudes and Baiu in Japan, J. Meteorol. Soc. Jpn., 63, 983-995, 1995.

Sano, M., Xu, C. X., and Nakatsuka, T.: A 300-year Vietnam hydroclimate and ENSO variability record reconstructed from tree ring $\delta^{18} \mathrm{O}$, J. Geophys. Res., 117, D12115, doi:10.1029/2012JD017749, 2012.

Simmonds, I., Bi, D., and Hope, P.: Atmospheric water vapor flux and its association with rainfall over China in summer, J. Climate, 12, 1353-1367, 1999.

Soderberg, K., Good, S. P., O’Connor, M., Wang, L., Ryan, K., and Caylor, K. K.: Using atmospheric trajectories to model the isotopic composition of rainfall in central Kenya, Ecosphere, 4, 118, 2013.

Tan, L. C., Cai, Y. J., Cheng, H., An, Z. S., and Edwards, R. L.: Summer monsoon precipitation variations in central China over the past 750 years derived from a high-resolution absoluted-dated stalagmite, Palaeogeogr. Palaeocl., 280, 432-439, 2009.

Tian, L., Masson-Delmotte, V., Stievenard, M., Yao, T., and Jouzel, J.: Tibetan Plateau summer monsoon northward extent revealed by measurements of water stable isotopes, J. Geophys. Res., 106, 28081-28088, 2001.

Tierney, J. E., Russell, J. M., Huang, Y. S., Sinninghe Damsté, J. S., Hopmans, E. C., and Cohen, A. S.: Northern hemisphere controls on tropical southeast Africa climate during the past 60000 years, Science, 322, 252-255, 2008.

Tremoy, G., Vimeux, F., Mayaki, S., Souley, I., Cattani, O., Risi, C., Favreau, G., and Oi, M.: A 1-year long $\delta^{18} \mathrm{O}$ record of water vapor in Niamey (Niger) reveals insightful atmospheric processes at different timescales, Geophys. Res. Lett., 39, L08805, doi:10.1029/2012GL051298, 2012.

Vimeux, F., Tremoy, G., Risi, C., and Gallaire, R.: A strong control of the South American SeeSaw on the intra-seasonal variability of the isotopic composition of precipitation in the Bolinian Andes, Earth. Planet. Sc. Lett., 307, 47-58, 2011.

Vuille, M., Werner, M., Bradley, R. S., and Keimig, F.: Stable isotopes in precipitation in the Asian monsoon region, J. Geophys Res., 110, D23108, doi:10.1029/2005JD006022, 2005. 
Wang, B. and Xu, X. H.: Northern Hemisphere summer monsoon singularities and climatological intraseasonal oscillation, J. Climate, 10, 1171-1185, 1997.

Wang, Y. J., Cheng, H., Edwards, R. L., An, Z. S., Wu, J. Y., Chen, C. C., and Dorale, J. A.: A high-resolution absolute-dated Late Pleistocene Monsoon record from Hulu Cave, China, Science, 294, 2345-2348, 2001.

Wang, Y. J., Cheng, H., Edwards, R. L., Kong, X. G., Shao, X. H., Chen, S. T., Wu, J. Y., Jiang, X. Y., Wang, X. F., and An, Z. S.: Millennial-and orbital-scale changes in the East Asian Monsoon over the past 224,000 years, Nature, 451, 1090-1093, 2008.

Werner, M., Langebroek, P. M., Carlsen, T., Herold, M., and Lohmann, G.: Stable water isotopes in the ECHAM5 general circulation model: Toward high-resolution isotope modeling on a global scale, J. Geophy. Res., 116, D15109, doi:10.1029/2011JD015681, 2011.

Xie, L. H., Wei, G. J., Deng, W. F., and Zhao, X. L.: Daily $\delta^{18} \mathrm{O}$ and $\delta$ D of precipitations from 2007 to 2009 in Guangzhou, South China: Implications for changes of moisture sources, J. Hydrol, 400, 477-489, 2011.
Yang, X. X., Yao, T. D., Yang, W. L., Xu, B. Q., He, Y., and Qu, D. M.: Isotopic signal of earlier summer monsoon onset in the Bay of Bengal, J. Climate, 25, 2509-2515, doi:10.1175/JCLI-D-11$00180.1,2012$.

Yuan, D. X., Cheng, H., Edwards, R. L., Dykoski, C. A., Kelly, M. J., Zhang, M. L., Qing, J. M., Lin, Y. S., Wang, Y. J., Wu, J. Y., Dorale, J. A., An, Z. S., and Cai, Y. J.: Timing, duration and transition of the last interglacial Asian monsoon, Science, 304, 575-578, 2004.

Zhang, P. Z., Cheng, H., Edwards, R. L., Chen, F. H., Wang, Y. J., Yang, X. L., Liu, J., Tan, M., Wang, X. F., Liu, J. H., An, C. L., Dai, Z. B., Zhou, J., Zhang, D. Z., Jia, J. H., Jin, L. Y., and Johnson, K. R.: A test of climate, sun, and culture relationships from an 1810-year Chinese cave record, Science, 322, 940-942, 2008 . 